\title{
Serosurvey Of Selected Avian Pathogens In Brazilian Commercial Rheas (Rhea americana) And Ostriches (Struthio camelus)
}

Author(s)
Freitas Neto OC de ${ }^{1}$
Carrasco AOT ${ }^{2}$
Raso TF ${ }^{3}$
Sousa RLM
Berchieri Júnior $A^{1}$
Pinto AA 1
1 Department of Veterinary Pathology,
Universidade Estadual Paulista, Jaboticabal,
São Paulo, Brazil
2 Department of Veterinary Medicine,
Universidade Estadual do Centro-Oeste,
Guarapuava, Paraná, Brazil
Department of Pathology, Universidade de
São Paulo, São Paulo, São Paulo, Brazil
Department of Basics Sciences, Universidade
de São Paulo, Piracicaba, São Paulo, Brazil

\section{Mail Address}

Adriano Oliveira Torres Carrasco Departamento de Medicina Veterinária Universidade Estadual do Centro-Oeste 85.040-08. Guarapuava, Paraná, Brazil Telefone: +55 4236298216

E-mail: adriano.carrasco@gmail.com
Chlamydophila psittaci, Mycoplasma spp., Newcastle Disease virus, ostrich, rhea, Salmonella spp., serology

\section{Acknowledgements}

The authors are grateful to Fundação de Amparo à Pesquisa do Estado de São Paulo FAPESP (00/03362-0; 04/13868-0; 05/58237$0)$ and to Conselho Nacional de Desenvolvimento Científico e Tecnológico - CNPq (521722/93-4) for their financial support.

\section{ABSTRACT}

Ratite farming of has expanded worldwide. Due to the intensive farming methods used by ratite producers, preventive medicine practices should be established. In this context, the surveillance and control of some avian pathogens are essential for the success of the ratite industry; however, little is known on the health status of ratites in Brazil. Therefore, the prevalence of antibodies against Newcastle Disease virus, Chlamydophila psittaci, Mycoplasma gallisepticum, Mycoplasma synoviae, and Salmonella Pullorum were evaluated in 100 serum samples collected from commercial ostriches and in 80 serum samples from commercial rheas reared in Brazil. All sampled animals were clinically healthy. The results showed that all ostriches and rheas were serologically negative to Newcastle disease virus, Chlamydophila psittaci, Mycoplasma gallisepticum, and Mycoplasma synoviae. Positive antibody responses against Salmonella Pullorum antigen were not detected in ostrich sera, but were detected in two rhea serum samples. These results can be considered as a warning as to the presence of Salmonella spp. in ratite farms. Therefore, the implementation of good health management and surveillance programs in ratite farms may contribute to improve not only animal production, but also public health conditions.

\section{INTRODUCTION}

The farming of ratites (ostriches, emus, and rheas) has expanded considerably all over the world in recent years. In Brazil, the commercial breeding of ostriches (Struthio camelus) and rheas (Rhea americana) has also increased. Due to intensive farming methods used by ratite producers, preventive medicine practices, such as disease monitoring and surveillance, should be established. Thus, health surveillance is important to the ratite industry, and may also influence the trade of other types of poultry at the international level (Ley et al., 2000).

Newcastle disease is an acute and highly contagious viral disease of birds, which can cause high (up to 100\%) mortality in chickens, the most important natural host of the disease; however, it can also affect a wide variety of avian species, also causing severe disease (Alexander, 1997). Newcastle disease is endemic in many countries, and it is caused by an avian Paramyxovirus type 1 (APMV-1), which is a member of the genus Avulavirus of the Paramyxoviridae family (Mayo, 2002). As demonstrated by intensive surveys, nearly 236 species from 27 of the 50 orders of birds were reported to be susceptible either to natural or experimental infection with Newcastle virus (Kaleta \& Baldauf, 1988; Wan et al., 2004, Carrasco et al., 2008) and, on several occasions, Newcastle disease virus (NDV) was isolated from some free-living birds (Alexander \& Parsons, 1986). Ratites are susceptible to many diseases of domestic fowl, including Newcastle disease (Samberg et al., 1989; 
Freitas Neto OC de, Carrasco AOT, Raso TF, Sousa RLM, Berchieri Júnior A, Pinto AA
Serosurvey Of Selected Avian Pathogens In Brazilian Commercial Rheas (Rhea americana) And Ostriches (Struthio camelus)
Koch et al., 1998). Efforts to control and prevent this disease through efficient vaccination programs and corresponding serological monitoring in ratites have been adopted (Sousa et al., 2000).

Chlamydiosis is an infectious disease caused by Chlamydophila psittaci (C. psittaci). The list of Chlamydophila-positive birds includes six major domestic species (chicken, turkey, Peking duck, Muscovy duck, goose, and pigeon), three minor domestic species (Japanese quail, bobwhite quail, and peafowl), as well as 460 free-living or pet bird species belonging to 30 orders (Kaleta \& Taday, 2003). Clinical signs of chlamydiosis include anorexia, dyspnea, dehydration, diarrhea with yellowish-green urates, weight loss, conjunctivitis, rhinitis, and sinusitis. Many of the affected birds become chronically infected, but only present clinical signs when stressed. Most carriers may intermittently shed C. psittaci, and are a significant source of infection both for humans and other birds (Fudge, 1996). This microorganism is responsible for an occupational zoonosis called psittacosis, which is a health hazard for pet owners, veterinarians, and workers of poultry abattoirs and processing plants. However, there are few studies in this disease in ratites (Camus et al., 1994; Andersen et al., 1998; Uhart et al., 2006), and little is known on the pathogenesis and the significance of the humoral antibody response in Brazilian ratites flocks.

Mycoplasma spp. has been implicated in economic losses in the poultry industry. It causes reduced egg production, worse feed efficiency, increase in mortality rates, as well as carcass condemnations, in addition to increased medication costs (Nascimento et al., 2005). Mycoplasma spp. in ratites is usually associated with respiratory disease, causing inflammation of upper respiratory tract (Huchzermeyer, 1994). Poultry mycoplasms (Mycoplasma gallisepticum, Mycoplasma synoviae) have long been thought to be responsible for these infections (Verwoerd, 2000), and the search for antibodies against these microorganisms has been considered a useful tool to identify infected birds and to prevent the maintenance of mycoplasmosis in ratite farms (Cadman et al., 1994; Ley et al., 2000).

The genus Salmonella is divided in two species: Salmonella bongori and $S$. enterica, which is divided in six subspecies with several serovars (Popoff \& Minor 2001). More than 2,500 serovars have been described, but about ninety of them are more frequently involved in human and animal infections (Porwollik et al., 2004; CDC, 2007). There is little information on the occurrence of Salmonella spp. in ratites. According to literature,
Salmonella spp causes clinical signs and mortality in ratite chicks (Shivaprasad, 1993; Stewart, 1994; More, 1996). However, immunossupressed adults can shed Salmonella spp contributing to contamination of carcasses (Huchzermeyer, 1994; Gopo \& Banda, 1997; Ley et al., 2001; Gaedirelwe \& Sebunya, 2008), and, consequently, posing a risk to public health. The control and prevention of Salmonella spp in ratite farming are currently based on general hygiene and disinfection practices associated with bacteriological and serological exams (Tully \& Shane, 1996; Cooper, 2000; Ley et al., 2000; Black, 2001).

Little is known on the status of those diseases in ratites in Brazil. In this context, the objective of this study was to evaluate antibody responses to Newcastle Disease virus, Chlamydophila psittaci, Mycoplasma gallisepticum, Mycoplasma synoviae, and Salmonella Pullorum in serum samples collected from commercial ostriches (Struthio camelus) and commercial rheas (Rhea americana) reared in Brazil.

\section{MATERIAL AND METHODS}

\section{Sample collection}

One hundred blood samples collected from commercially raised slaughter-age ostriches and eighty blood samples from commercially raised slaughter-age rheas were assessed. Birds were reared in two dedicated ratite farms located in the southeast of Brazil. Birds were clinically healthy and had not been vaccinated against any avian pathogen.

Birds were manually restrained and samples were collected by jugular puncture with sterile needles and syringes. The blood was centrifuged at 2,000 xg for 10 minutes. The supernatant was then harvested and frozen in sterile plastic microtubes at $-20^{\circ} \mathrm{C}$ until tested. The ostriches sera was collected between 2006-2007, while the sera of rheas were collected between 19981999.

\section{Serologic test procedures}

Serodiagnostic of NDV was performed by hemagglutination inhibition (HI) test. Serum samples were treated with $25 \%(\mathrm{w} / \mathrm{v})$ kaolin solution (Carrasco et al., 2008). The $\mathrm{HI}$ test was performed in microtitration plate using four hemagglutination units (UHA) of NDV LaSota vaccine strain propagated in the allantoic cavity of 9- to 10-day-old embryonated specific pathogen free (SPF) eggs. Results were recorded as $\log _{2} X$ values of the highest reciprocal of the dilution presenting hemagglutination inhibition. 
Freitas Neto OC de, Carrasco AOT, Raso TF, Sousa RLM, Berchieri Júnior $A$, Pinto $A A$
Serosurvey Of Selected Avian Pathogens In Brazilian Commercial Rheas (Rhea americana) And Ostriches (Struthio camelus)
Birds with $\mathrm{HI}$ titers equal to or higher than $4 \log _{2}$ were considered positive for NDV (O.I.E., 2004).

Serodiagnostic of chlamydiosis was carried out by complement fixation test (CFT), according to the method described by Bier et al. (1968), and adapted to microplates by Raso et al. (2006). Briefly, $25 \mu \mathrm{L}$ of the test sera and $25 \mu \mathrm{L}$ of the chlamydial antigen, followed by $50 \mu \mathrm{L}$ of complement, were added to each well and incubated overnight at $4^{\circ} \mathrm{C}$. Subsequently, $25 \mu \mathrm{L}$ of sensitized sheep red blood cells were added to each well and the plates were incubated for $30 \mathrm{~min}$ at $37^{\circ} \mathrm{C}$. Controls for serum and antigen were included in every run, as well as for the complement and the hemolytic system. Finally, plates were centrifuged at $800 \times \mathrm{g}$ for $5 \mathrm{~min}$ and the degree of lysis was visually assessed. Samples showing more than $50 \%$ lysis at serum dilutions of 1:16 or higher in the presence of 2 units of complement were considered positive.

Serum samples were also tested for Mycoplasma gallisepticum, Mycoplasma synoviae, and Salmonella Pullorum by serum plate agglutination using commercial antigens (Myco-Galli Teste ${ }^{\circledR}$, Synovitest ${ }^{\circledR}$ and Pulor-teste ${ }^{\circledR}$, Biovet, São Paulo, Brazil). The tests were conducted by mixing a drop $(50 \mu \mathrm{L})$ of serum samples with a drop (50 $\mu \mathrm{L}$ ) of antigen on a clean glass plate at room temperature $\left(25^{\circ} \mathrm{C}\right)$. Serum samples and antigen were mixed until homogenous distribution was achieved. The glass plate was rotated for five seconds, left resting for one minute, and then read. Samples presenting agglutination, asshown by the formation of clots, were considered positive. Positive and negative serum controls were used.

\section{RESULTS}

All serum samples from ostriches and rheas were negative for NDV in the $\mathrm{HI}$ test, for Chlamydophila psittaci in CFT, as well as for Mycoplasma gallisepticum and Mycoplasma synoviae antigens in serum plate agglutination tests. Additionally, all ostrich serum samples were negative for Salmonella Pullorum in serum plate agglutination test. However, two serum samples $(2.5 \%)$ were positive for the commercial Salmonella Pullorum antigen (Table 1).

\section{DISCUSSION AND CONCLUSIONS}

All sampled birds were apparently healthy, with no evidence of disease, and all were serologically negative for the Newcastle disease virus, Chlamydophila psittaci, Mycoplasma gallisepticum, and Mycoplasma synoviae.

Our results indicated that the population of ratites in this study was not previously exposure to NDV. However, in an earlier investigation with Brazilian Rhea americana, antibodies against NDV were detected in $56 \%$ of samples by $\mathrm{HI}$ test (Sousa et al., 2000). Deaths due to NDV have been reported in ratites in many foreign countries (Huchzermeyer, 1994; Williams et al., 1997; Verwoerd, 2000).

It is important to highlight that the hemagglutination inhibition technique tends to yield false positive results in serum samples of some species, including ostriches, due to the presence of nonspecific hemagglutination inhibitors (Willians et al., 1997; Alexander, 1997; Koch et al., 1998; Sousa et al., 2000). According to the OIE (2004), serum samples can be incubated with $10 \%$ chicken red blood cell (RBC) suspension at room temperature for $10 \mathrm{~min}$ in order to eliminate those agents. Additionally, other serum treatments based on kaolin (used in the present study), periodate, heparinmanganese, and acetone have been also used to eliminate these inhibitors (Hovi, 1978).

Although C. psittaci appears to be widespread among Brazilian psittacine birds, evidence of exposure or disease has not been reported in ratites to date in Brazil (Raso, 2006). In the present study, all birds were Chlamydophila-negative. Few reports of the disease in ratites have been published in the world. Cases of chlamydiosis in commercial rheas were reported in the United States of America, when birds were found dead without exhibiting any signs of the disease (Camus et al., 1994). Eleven isolates from a number of ratites (10 from rheas and one from ostrich) were serotyped and characterized by diagnostic laboratories in Texas and California (Andersen et al., 1998). All isolates were determined to be serovar $E$, although the origin of the natural host of this serovar is not known. Moreover, antibodies against Chlamydophila were found in $92.6 \%$

Table 1 - Results of the serological survey of antibodies against selected avian pathogens in ostriches and rheas reared in the southeast of Brazil.

\begin{tabular}{lccc}
\hline Avian pathogen & Test & Positive in test & Ostriches \\
\hline Newcastle Disease Virus & H & Titer: $\geq 16$ & $0 / 100$ \\
Chlamydophila psittaci & CFT & Titer: $\geq 16$ & $0 / 100$ \\
Mycoplasma gallisepticum & Agglutination test & Agglutination & $0 / 80$ \\
Mycoplasma synoviae & Agglutination test & Agglutination & $0 / 100$ \\
Salmonella Pullorum & Agglutination test & Agglutination & $0 / 100$ \\
\hline
\end{tabular}


Freitas Neto OC de, Carrasco AOT, Raso TF, Sousa RLM, Berchieri Júnior $A$, Pinto $A A$
Serosurvey Of Selected Avian Pathogens In Brazilian Commercial Rheas (Rhea americana) And Ostriches (Struthio camelus)
(25/27) of free-ranging adults and semicaptive juvenile rheas tested in Argentina (Uhart et al., 2006).

Antibody responses to poultry mycoplasmas have been described in ratites (Cadman et al., 1994; Peccati et al., 1995). However, in the present study, no positive serological responses to Mycoplasma gallisepticum or Mycoplasma synoviae were found neither in rheas nor in ostriches. These results are consistent with the findings of other authors (Shane \& Tully, 1996; Ley et al., 2000), who reported no positive serological responses to Mycoplasma gallisepticum or Mycoplasma synoviae in any of common ratite species. According to literature, Mycoplasma spp. in ostriches would be associated with respiratory disease, causing inflammation of the upper respiratory tract (Huchzermeyer, 1994; Verwoerd, 2000). On the other hand, in our study, none of examined birds presented any clinical signs of the disease.

Some authors have suggested that ostriches may harbor unique species-specific mycoplasmas different from Mycoplasma gallisepticum, Mycoplasma synoviae, Mycoplasma meleagridis, or Mycoplasma iowae, which are typically associated with respiratory infections in poultry (Shivaprasad, 1993; Shane, 1998; Botes et al., 2005). In this case, commercial Mycoplasma gallisepticum and Mycoplasma synoviae antigens would not be suitable to test ratite sera. Therefore, this needs to be further investigated.

The serum plate agglutination test with Salmonella Pullorum antigen is one of available methods to evaluate antibody responses in poultry. It allows identifying birds that are or were infected with serovars belonging to serogroup "D" (Davies \& Wray, 1994). However, some studies have shown no antibody responses to Salmonella Pullorum antigen in the sera of ostriches or rheas (Pereira, 2007; Ley et al., 2000). In the present study, positive antibody responses to Salmonella Pullorum antigen were not observed in ostrich sera, but were detected in two rhea serum samples. These results suggest that the tested ostriches were not infected with serogroup "D" Salmonella serovars, and that the two positive rheas could have been infected with some serovar of serogroup "D" (e.g. Salmonella Enteritidis, Salmonella Pullorum and Salmonella Gallinarum).

Ratite farming system is based on rearing birds on pastures in paddocks surrounded by fences (Tully \& Shane, 1996; Cooper, 2000; Black, 2001). This practice could favor contact with wild animals (birds, rodents, and insects) capable of transmitting Salmonella spp. (Tully \& Shane, 1996; Connolly et al., 2006; Pennycott et al., 2006). In addition, feed may be an important source of Salmonella spp. in ratite production. Feed may be contaminated during the storage process or even during manufacturing, and, as a result, it could play an important role in the introduction or maintenance of Salmonella spp. in ratite farms (Gopo \& Banda, 1997; Higgins et al., 1997; Freitas Neto et al., 2009). In the present study, it was not possible to determine how rheas were infected because an epidemiological investigation was not performed; however, this result should be considered as a warning as to presence of Salmonella spp in ratite farms. Therefore, the implementation of good health management should not be overlooked.

Finally, serological tests are tools used for surveillance in ratite farming; however, the use of these methods in ratites needs to be further investigated. Therefore, other tests are also required, as false negative or positive results may provide an incorrect interpretation of the flock health status or determine an inadequate management strategy in the farm.

\section{REFERENCES}

Alexander DJ. Newcastle disease and other avian paramyxoviridae infections. In: Calnek BW, Barnes HJ, Beard C, McDougald LR, editor. Diseases of poultry. Ames: lowa State University Press; 1997. p.541-569.

Alexander DJ, Parsons G. Pathogenicity for chickens of avian paramyxovirus type 1 isolates obtained from pigeons in Great Britain during 1983-1985. Avian Pathology 1986; 15:487-493.

Andersen AA, Grimes JE, Shivaprasad HL. Serotyping of Chlamydia psittaci isolates from ratites. Journal of Veterinary Diagnostic Investigation 1998; 10:186-188.

Bier O, Siqueira M, Esteves MB. Quantitative studies of complement fixation. I. A simplified and accurate procedure based on $50 \%$ hemolytic end point. Revista do Instituto de Medicina Tropical de São Paulo 1968; 10:199-208.

Black D. Ostrich flock health. Seminars in Avian and Exotic Pet Medicine 2001; 10(1):117-130.

Botes A, Peyrot BM, Olivier AJ, Burger WP, Bellsted DU. Identification of three novel Mycoplasma species from ostriches in South Africa. Veterinary Microbiology 2005; 111:159-169.

Centers for Diseases Control and Prevention. Salmonella: annual summary 2005. Georgia: US Department of Health and Human Services; 2007. 79p.

Cadman HF, Kelly PJ, Zhou R, Davelaar F, Mason PR. A serosurvey using enzyme-linked immunosorbent assay for antibodies against poultry pathogens in ostriches (Struthio camelus) from Zimbabwe. Avian Diseases 1995; 38:621-625. 
Camus AC, Cho DY, Poston RP, Psulsen DP, Oliver JL, Law MJ, Tully TN. Chlamydiosis in commercial rheas (Rhea americana). Avian Diseases 1994; 38:666-671.

Carrasco AOT, Freitas Neto OC, Lages SL, Souza RLM, Berchieri Junior A, Pinto AA. Adaptation of Hemagglutination Inhibition Technique $(\mathrm{HI})$ for the Diagnosis of Newcastle Disease in Ostriches (Struthio camellus). Virus Reviews \& Research 2008; 13:1-11.

Carrasco AOT, Seki MC, Raso TF, Paulillo AC, Pinto AA. Experimental infection of Newcastle disease virus in pigeons (Columba livia): Humoral antibody response, contact transmission and viral genome shedding. Veterinary Microbiology 2008; 129(1-2):89-96.

Connolly JH, Alley MR, Dutton GJ. Infectivity and persistence of an outbreak strain of Salmonella Typhimurium DT 160 for house sparrows (Passer domesticus) in New Zeland. New Zealand Veterinary Journal New Zealand 2006; 54(6):329-332.

Cooper RG. Critical factors in ostrich (Struthio camelus) production: a focus on southern Africa. World's Poultry Science Journal 2000; 56(3):247-265.

Davies RH, Wray C. Guideline on detection and monitoring of Salmonella infected poultry flocks with particular reference to Salmonella enteritidis. Austria: World Health Organization ; 1994.

Freitas Neto OC, Lages SL, Carrasco AOT, Berchieri Junior A. Search for Salmonella spp. in ostrich productive chain of Brazilian southeast region. Tropical Animal Heath and Production 2009. In press.

Fudge AM. Avian chlamydiosis. In: Rosskopf Jr WJ, Woerpel RW, editors. Diseases of caged and aviary birds. Malvem: Williams and Wilkins; 1996. p.572-585.

Gaedirelwe OG, Sebunya TK. The Prevalence and Antibiotic Susceptibility of Salmonella sp. In Poultry and ostrich Samples from Slaughter Houses in Gaborone, Botswana. Journal of Animal and Veterinary advances 2008; 7:1151-1154

Gopo JM, Banda GN. Occurrence of Salmonella on meat and products in an ostrich abattoir as determined with a DNA probe. South African Journal of Animal Science 1997; 27(1):1-6.

Higgins RA, Desilets M, Cantin S, Messeier R, Khakhria J, Ismail MR, Mulvey D, Caron H. Outbreak of Salmonella give in province of Quebec. The Canadian Veterinary Journal 1997; 38(12):780-781.

Hovi T. Nonspecific inhibitors of coronavirus OC43 haemagglutination in human sera. Medical Microbiology and Immunology 1978; 166:173-176.

Huchzermeyer FW. Ostrich diseases. Onderstepoort: South Africa: Agricultural Research; 1994. p. 23.

Kaleta EF, Baldauf C. Newcastle disease in free-living and pet birds. In: Alexander JD, editor. Newcastle disease. Boston: Kluwer Academic; 1988. p.197-246.

Kaleta EF, Taday EMA. Avian host range of Chlamydophila spp. based on isolation, antigen detection and serology. Avian Pathology 2003; 32(5):435-462.
Koch G, Czifra G, Engström BE. Detection of Newcastle disease virus-specific antibodies in ostrich sera by three serological methods. The Veterinary Record 1998; 4:10-12.

Ley EC, Morishita TY, Harr BS, Mohan R, Brisker T. Serologic survey of slaughter-age ostriches (Struthio camelus) for antibodies to select avian pathogens. Avian Diseases 2000; 44:989-992.

Ley EC, Morishita TY, Brisker T, Harr BS. Prevalence of Salmonella, Campylobacter, and Escherichia coli on ostrich carcasses and the susceptibility of ostrich $E$. coli isolates to various antibiotics. Avian Diseases 2001; 45:696-700.

Mayo MA. Virus taxonomy. Archives of Virology 2002; 147: 1071 1076.

More SJ. The Performance of farmed ostrich chicks in eastern Australia. Preventive Veterinary Medicine 1996; 29(1):91-106.

Nascimento ER, Pereira VLA, Nascimento MGF, Barreto ML. Avian Mycoplasmosis update. Revista Brasileira de Ciência Avícola 2005; 1(1):1-9.

OIE. Newcastle disease. In: Office International Des Epizooties Manual of standards for diagnostic tests and vaccines. 5th ed. Paris; 2004.

Peccati C, Grilli G, Ramoin T, Gallazi D. Newcastle disease, avian influenza, Salmonella pullorum gallinarum and Mycoplasma screening in ostriches in northern Italy. Conference of the European Committee Association of Avian Veterinarians; 1995; Orlando, Florida, The United States of America. p.48-50.

Pennycott TW, Park A, Mather HA. Isolation of different serovars of Salmonella enterica from wild birds in great Britain between 1995 and 2003. Acta Veterinaria Scandinavica 2006; 46(4):193201.

Pereira RA. Pesquisa e detecção de Salmonella sp. em emas (Rhea americana): Estudos bacteriológicos, sorológicos e reação em cadeia pela polimerase tese. Porto Alegre (RS): Faculdade de Veterinária, Universidade Federal do Rio Grande do Sul; 2007.

Popoff MY, Minor L. Antigenic formulas of the Salmonella serovars. 8th rev. Paris: WHO Collaborating Center for Reference and Research on Salmonella, Institut Pasteur; 2001.

Porwollik S, Boyd EF, Choy C, Cheng P, Florea L, Proctor E, McClelland M. Characterization of Salmonella enterica subspecies I genovars by use of microarrays. Journal of bacteriology 2004; 186:58835898.

Raso TF. Clamidiose. In: Cubas ZS, Silva JCR, Catão-Dias JL, editor. Tratado de animais selvagens: medicina veterinária. São Paulo: Roca; 2006. p.760-767.

Raso TF, Seixas GHF, Guedes NMR, Pinto AA. Chlamydophila psittaci in free-living Blue-fronted Amazon parrots (Amazona aestiva) and Hyacinth macaws (Anodorhynchus hyacinthinus) in the Pantanal of Mato Grosso do Sul, Brazil. Veterinary Microbiology 2006; 117(2-4):235-241. 
Shane SM. Infectious diseases and parasites of ratites. In: Shane SM, Tully TN, Hunt E, editor. Veterinary Clinics Of North America: Food Animal Practice, Ratites. Philadelphia: Saunders; 1998. p.455-483.

Shane SM, Tully TN. Infectious diseases. In: Tully TN, Shane SM, editor. Ratite management, medicine, and surgery. Malabar: Krieger Publishing; 1996. p.127-146.

Samberg V, Hadash DV, Perelman B, Meroz M. Newcastle disease in ostriches (Struthio camelus): field case and experimental infection. Avian Pathology 1989; 18:221-226.

Shivaprasad HL. Neonatal mortality in ostriches: An overview of possible causes. Annual Conference of the European Committee Association of Avian Veterinarians; 1993; San Diego, California. The United States of America. p.283-293.

Sousa RLM, Montassier HJ, Pinto AA. Detection and quantification of antibodies to Newcastle Disease Virus in ostrich and rhea sera using a liquid phase blocking enzyme-linked immunosorbent assay. Clinical and Diagnostic Laboratory Immunology 2000; 7: 940-944.

Stewart J. Ratites. In: Ritchie BW, Harrison GJ, Harrison LR, editor. Avian medicine: principles and application. Lake Worth: Wingers Publishing; 1994. p.1285-1326.

Tully TN, Shane SM. Husbandry practices as related to infectious and parasitic diseases of farmed ratites. Revue Scientifique et Technique 1996; 15(1):73-89.

Uhart M, Aprile G, Beldomenico P, Solís G, Marull C, Beade M, Carminati A, Moreno D.Evaluation of the health of free-ranging greater rheas (Rhea americana) in Argentina. The Veterinary Record 2006; 158:297-303.

Verwoerd DJ. Ostrich diseases. Revue Scientifique et Technique 2000; 19(2):38-61.

Wan $\mathrm{H}$, Chen L, Wu L, Liu X. Newcastle disease in geese: natural occurrence and experimental infection. Avian Pathology 2004; 33:216-221.

Willians R, Boshoff $\mathrm{CH}$, Vervoerd D, Schoemen M, Van Wyk A, Gerdes TH, Roos K. Detection of antibodies no Newcastle Disease Virus in ostriches (Strutio camelus) by an indirect ELISA. Avian Diseses 1997; 41:864-869. 